\title{
Deskripsi Sikap Kesenangan dalam Belajar IPA, Ketertarikan Memperbanyak Waktu Belajar IPA, dan Ketertarikan Berkarir di Bidang IPA di MTS Syifa'ul Qulub
}

\author{
Risma Setya Suryani1 ${ }^{1}$, Rini Siski Fitriani ${ }^{2}$ \\ ${ }^{1}$ Guru IPA MtS Syifa'ul Qulub \\ ${ }^{2}$ Program Studi Pendidikan Fisika, Universitas Jambi
}

\section{Article Info}

Article history:

Received Dec 29, 2019

Revised Dec 31, 2019

Accepted Jan 01, 2020

\section{Keywords:}

Sikap

Kesenangan dalam Belajar

Ketertarikan

\begin{abstract}
Tujuan Penelitian: Tujuan dari penelitian ini adalah untuk mengetahui bagaimana sikap siswa Mts Syifa'ul Qulub terhadap IPA pada tiga indikator yaitu kesenangan dalam belajar IPA, ketertarikan memperbanyak waktu belajar IPA, dan ketertarikan berkarir di bidang IPA
\end{abstract}

Metedologi: Penelitian ini adalah jenis penelitian kuantitatif dengan analisis data deskriptif. Data yang dihasilkan dari penelitian kuantitatif adalah berupa angka/numerik. Subjek dari penelitian ini adalah 73 siswa-siswi di Mts Syifaul Qulub.

Hasil Temuan: Hasil penelitian yang diperoleh yaitu dari tiga indikator kesenangan belajar IPA, ketertarikan memperbanyak waktu belajar IPA, dan ketertarikan berkarir di bidang IPA di Mts Syifa'ul Qulub sikap yang paling dominan adalah pada kategori cukup.

Keterbaruan Penelitian: Keterbaruan dari penelitian ini adalah indikator yang digunakan untuk mendeskripsikan sikap IPA di MtS Syfa'ul Qulub. Adapun indikator yang digunakan pada penelitian ini ialah kesenangan dalam belejar IPA, ketertarikan memperbanyak waktu belajar IPA, dan ketertariakn berkarir di bidang IPA

This is an open access article under the $\mathrm{CC} B Y-N C$ license

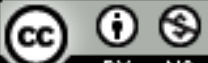

Corresponding Author:

Risma Setya Suryani, Guru IPA MTS Syifa'ul Qulub, Kabupaten Tebo,

Email: rismasetyasuryani215@gmail.com

\section{PENDAHULUAN}

Pendidikan merupakan proses pembelajaran untuk meningkatkan pengetahuan dan keterampilan seseorang agar menjadi manusia yang berkualitas yang mampu menghadapi tantangan masa depan. Pendidikan menjadi hal yang sangat penting untuk menjadikan peserta didik dapat menggapai cita-citanya melalui wawasan dan ilmu yang telah didapat dari suatu pendidikan [1]. Sejalan dengan pendapat [2] pendidikan akan membentuk pribadi yang layak dalam lingkungan keluarga dan juga masyarakat. Education is an ongoing process that aims to increase the quality of human resources [3]. Mata pelajaran IPA terdapat pada jenjang sekolah menengah pertama (SMP). IPA merupakan salah satu mata pelajaran di SMP yang memegang peran penting dalam membentuk siswa yang berkualitas.

Sikap merupakan bentuk dari pikiran dan perasaan seseorang untuk mengenal aspek-aspek tertentu dalam lingkungannya yang tidak mudah untuk dirubah [4-7]. Sikap adalah pandangan atau perasaan yang disertai kecenderungan untuk bertindak terhadap suatu obyek tertentu [8]. Attitude is the tendency to act, perceive, think and feel in the face of objects, ideas, situations, or values [9-10]. Sikap adalah hal yang 
penting dalam pembelajaran karena mempengaruhi hasil belajar siswa. Hal pertama yang dapat dilihat dari siswa menyukai atau tidak terhadap pelajaran IPA adalah bagaimana sikap siswa saat pelajaran berlangsung. Sikap siswa terhadap mata pelajaran IPA dilihat dari bagaimana tanggapan mereka tentang pelajaran IPA, secara umum, sikap siswa pada IPA ada yang positif dan juga negatif [11].

Kesenangan dalam belajar IPA merupakan salah satu sikap positif siswa yang berarti rasa suka siswa saat sedang belajar IPA yang diikuti dengan rasa ingin tahu yang tinggi [12]. Kesenangan belajar dalam IPA dapat didefinisikan bahwa setiap siswa yang memiliki sikap positif terhadap IPA harus memiliki kenyamanan dan merasakan kesenangan [13]. Ketertarikan adalah keadaan dimana seseorang merasa tertarik akan sesuatu. Sikap ketertarikan dalam memperbanyak waktu belajar IPA sangatlah bagus, itu artinya siswa mempunyai motivasi yang tinggi untuk terus belajar IPA[14-15]. Ketertarikan dalam memperbanyak waktu belajar IPA adalah sebagai ungkapan kesukaan siswa dalam mempelajari IPA dengan memanfaatkan waktu luang untuk mempelajari lebih dalam pelajaran IPA [16]. Ketertarikan berkarir dibidang IPA merupakan keinginan untuk sudah harus ditanamkan pada siswa.

Berdasarkan uraian di atas, peneliti berasumsi bahwa perlu diadakannya penelitian tentang bagaimana sikap siswa pada mata pelajaran IPA di MtS Syifa'ul Qulub. Hal ini bertujuan agar guru memiliki tolak ukur/patokan yang jelas tentang sikap siswa terhadap mata pelajaran IPA. Pengukuran sikap siswa terhadap mata pelajaran IPA pada penelitian ini menggunakan instrumen angket. Adapun indikator dari instrumen tersebut adalah, kesenangan dalam belajar IPA, ketertarikan memperbanyak waktu belajar IPA, dan ketertarikan berkarir di bidang IPA

\section{METODE}

Penelitian ini adalah jenis penelitian kuantitatif dengan analisis data deskriptif. Penelitian ini menggunakan metode kuantitatif deskriptif desain survei. Survey research design is used in quantitative research methods to see attitudes, behavior, population characteristic, and opinions, generraly the research sample can use questionnaire, and interviews, and statisticaly analyzed using numbers [17]. Data yang dihasilkan dari penelitian kuantitatif adalah berupa angka/numerik. Analisis data, pada penelitian ini menggunakan data analisis kuantitatif menggunakan program SPSS untuk mencari statistik deskriptif, statistik deskriptif merupakan suatu gambaran atau penyajian data dalam jumlah besar, dalam hal ini berupa frekuensi ringkasan, misalnya modus, mean, median, minimum, maksimum dan standar deviasi [18].

Instrument dari penelitian ini erupa angket yang diadopsi dari penelitian Astalini \& Kurmiawan (2019) yang berjudul "Pengembangan Instrumen Sikap Siswa Sekolah Menengah Pertama Terhadap Mata Pelajaran IPA" dengan nilai cronbach alpha 0.842. Subjek dari penelitian ini adalah 73 siswa-siswi di Mts Syifaul Qulub. Instrumen dari penelitian ini berupa angket sikap, dengan indikator kesenangan dalam belajar IPA dan ketertarikan memperbanyak waktu belajar IPA, dan ketertarikan berkarir di bidang IPA.

Tabel 1. Indikator Sikap Kesenangan, Ketertarikan Memperbanyak Waktu Belajar, dan Ketertarikan Berkarir di Bidang IPA

\begin{tabular}{clc}
\hline No & \multicolumn{1}{c}{ Indikator } & Jumlah Pernyataan \\
\hline $\mathbf{1}$ & Kesenangan dalam belajar IPA & 9 pernyataan \\
$\mathbf{2}$ & Ketertarikan memperbanyak waktu dalam belajar IPA & 8 pernyataan \\
$\mathbf{3}$ & Ketertarikan berkarir di bidang IPA & 9 pernyataan \\
\hline
\end{tabular}

\section{HASIL DAN PEMBAHASAN}

Keterbaharuan dari penelitian ini adalah indikator yang digunakan untuk mendeskripsikan sikap IPA di MtS Syfa'ul Qulub. Indikator yang digunakan pada penelitian sebelumnya [2] yang berjudul "Identifikasi Sikap Implikasi Sosial Dari Ipa, Tertarikan Menambah Waktu Belajar IPA, dan ketertarikan Berkarir di Bidang IPA Siswa Smp Sekabupaten Muaro Jambi”. Dalam penelitian tersebut indikator yang digunakan adalah identifikasi sikap Impilkasi sosial dari IPA, ketertarikan menambah waktu belajar IPA, dan ketertarikan berkarir di bidang IPA. Ada dua indikator yang sama dalam penelitian ini hanya satu indikator yang berbeda yaitu kesenangan dalam belajar IPA.

Adapun hasil dalam penelitian ini meliputi beberapa indicator yang digunakan ialah: 
Tabel 2. Kesenangan Belajar IPA

\begin{tabular}{|c|c|c|c|c|c|c|c|}
\hline Variabel & & terval & Frekuensi & $\begin{array}{c}\text { Persentasi } \\
(\%)\end{array}$ & Kategori & & \\
\hline \multirow{5}{*}{$\begin{array}{l}\text { Kesenangan } \\
\text { belajar IPA }\end{array}$} & 9,0 & $-16,20$ & 0 & 0 & Sangat Tidak Baik & Mean & 23,78 \\
\hline & 16,21 & $-\quad 23,4$ & 34 & 46.6 & Tidak Baik & Median & 24,00 \\
\hline & 23,41 & $-30,6$ & 38 & 52.1 & Cukup & Modus & 24,00 \\
\hline & 30,61 & $-\quad 37,8$ & 1 & 1.4 & Baik & Minimum & 17,00 \\
\hline & 37,81 & $-\quad 45,00$ & 0 & 0 & Sangat Baik & Maximum & 32,00 \\
\hline
\end{tabular}

Hasil analisis data statistik yang diperoleh di MtS Syifa'ul Qulub menegnai sikap siswa terhadap pelajaran IPA yang ditijau dari indikator kesenangan dalam belajar IPA dapat diukur melalui bagaimana sikap siswa saat pembelajaran berlangsung apakah rasa suka atau tidak suka. Berdasarkan data dari tabel 1.1 untuk indikator kesenangan dalam belajar IPA terdapat tiga kategori yaitu baik, cukup, dan tidak baik. Kategori baik yaitu 1,4 \% atau 1 orang siswa. Kategori cukup 52,1\% atau 38 siswa dan untuk kategori tidak baik ada $46.6 \%$ atau 34 siswa.

Tabel 3. Ketertarikan Memperbanyak Waktu Belajar IPA

\begin{tabular}{|c|c|c|c|c|c|c|}
\hline Variabel & Interval & Frekuensi & $\begin{array}{c}\text { Persentasi } \\
(\%)\end{array}$ & Kategori & & \\
\hline $\begin{array}{c}\text { Ketertarikan } \\
\text { memperbanyak } \\
\text { waktu belajar } \\
\text { IPA }\end{array}$ & $\begin{array}{c}8-14,4 \\
14,41-20,8 \\
20,81-27,2 \\
27,21-33,6 \\
33,61-40,00\end{array}$ & $\begin{array}{c}0 \\
14 \\
54 \\
4 \\
1\end{array}$ & $\begin{array}{c}0 \\
19,2 \\
74,0 \\
5,5 \\
1,4\end{array}$ & $\begin{array}{c}\text { Sangat Tidak Baik } \\
\text { Tidak Baik } \\
\text { Cukup } \\
\text { Baik } \\
\text { Sangat Baik }\end{array}$ & $\begin{array}{c}\text { Mean } \\
\text { Median } \\
\text { Modus } \\
\text { Minimum } \\
\text { Maximum }\end{array}$ & $\begin{array}{l}22,97 \\
23,00 \\
22,00 \\
15,00 \\
35,00\end{array}$ \\
\hline
\end{tabular}

Untuk indikator sikap ketertarikan memperbanyak waktu belajar IPA untuk ketgori sangat baik 1,4 $\%$ atau 1 siswa, kategori baik 5,5\% atau 4 siswa, kategori cukup adalah yang paling dominan yaitu 74,0 \% atau 54 siswa, kategori tidak baik 19,2\% atau $14 \%$, dan untuk kategori sangat tidak baik $0.7 \%$ atau hanya 1 orang siswa. Hasil analisis data statistik yang diperoleh di MtS Syifa'ul Qulub menegnai sikap siswa terhadap pelajaran IPA yang ditijau dari indikator ketertarikan memperbanyak waktu belajar IPA hal ini juga berkaitan erat dengan kesenangan dalam belajar IPA. Sikap ketertarikan memperbanyak waktu belajar IPA dapat dilihat bagaimana ketertarikan siswa dalam belajar IPA seperti membaca buku yang berkaitan dengan IPA saat jam kosong dan mengahiskan waktu untuk mencari informasi mengenai IPA di waktu luannya.

Tabel 4. Ketertarikan Berkarir di bidang IPA

\begin{tabular}{|c|c|c|c|c|c|c|c|}
\hline \multirow[t]{2}{*}{ Variabel } & \multicolumn{2}{|c|}{ Interval } & \multirow{2}{*}{$\begin{array}{c}\text { Frekuensi } \\
0\end{array}$} & \multirow{2}{*}{$\begin{array}{c}\begin{array}{c}\text { Persentasi } \\
(\%)\end{array} \\
0\end{array}$} & \multicolumn{3}{|l|}{ Kategori } \\
\hline & 9,0 & $-16,20$ & & & Sangat Tidak Baik & Mean & 24,49 \\
\hline Ketertarikan & 16,21 & $-\quad 23,4$ & 28 & 38,4 & Tidak Baik & Median & 25,00 \\
\hline Berkarir di & 23,41 & $-30,6$ & 42 & 57,5 & Cukup & Modus & 25,00 \\
\hline \multirow[t]{2}{*}{ bidang IPA } & 30,61 & $-\quad 37,8$ & 3 & 4,1 & Baik & Minimum & 19,00 \\
\hline & 37,81 & $-\quad 45,00$ & 0 & 0 & Sangat Baik & Maximum & 35,00 \\
\hline
\end{tabular}

Dan untuk indikator ketertarikan berkarir di bidang IPA ada tiga kategori. Kategori baik 4,1\% atau 3 siswa, kategori cukup 57,5 atau 42 siswa, dan kategori atau 38,4 \% atau 28 siswa. Dalam indikator ini sikap uang paling dominan adalah pada kategori cukup. Kesenangan dalam belajar IPA, ketertarikan memperbanyak waktu belajar IPA memilki keterkaitan dengan indikator ketertarikan berkarir di bidang IPA

Kesenangan dalam belajar IPA adalah siswa merasa senang dan antusias saat belajar. Kesenangan belajar dalam sains (IPA) dapat didefinisikan bahwa setiap siswa yang memiliki sikap positif terhadap sains harus memiliki kenyamanan dan merasakan kesenangan [19-21]. Faktor Kesenangan dalam belajar IPA ada faktor internal dan fator eksternal. Faktor internal atau dari dalam adalah perasaan yang timbul dari dalam diri siswa yang artinya siswa tersebut memang menyukai pelajaran IPA . Rasa senang dalam belajar IPA juga dipengaruhi oleh guru mata peljaran IPA itu sendiri. Guru yang menjelaskan mata pelajaran secara menarik akan membuat siswa senang belajar IPA dan juga seblaiknya jika dalam penyampaian materi IPA tidak menarik maka akan membuat siswa kurang berminat pada pelajaran IPA yang membuatnya mempunyai sikap negatif ini merupakaan faktor eksternal[22-26]. Ketertarikan dalam memperbanyak waktu belajar IPA artinya siswa merasa senang dalam belajar IPA sehingga membuat siswa akan mempergunakan waktu luangnya untuk memperbanyak waktu belajar IPA. Ketertarikan berkarir dibidang IPA berarti siswa memiliki minat untuk berkarir di bidang IPA, yaitu ingin menjadi saintis atau ilmuwan yang berkenaan dengan IPA.

Sikap dalam belajar terdiri dari sikap positif dan juga sikap negatif. Sikap positif yang timbul, misalnya semangat saat kegiatan belajar mengajar, rasa senang dan ingin tahu terhadap materi pelajaran IPA. Sedangkan sikap negatif yang timbul seperti kurang tertarik mengikuti pelajaran, malas mendengarkan 
penjelasan dari guru, tidak semangat dan jenuh saat proses pembelajaran IPA dan lain sebagainya. Penerimaan atau sikap positif dan penolakan atau sikap negatif dapat dinyatakan dengan sikap persetujuan atau tidak persetujuan terhadap pernyataan sesuatu objek [27]. Keberhasilan siswa menyerap secara baik materi yang disampaikan guru dalam proses pembelajaran akan menimbulkan hasil belajar IPA positif pada individu siswa tersebut [28].

Tiap indikator dalam penelitian ini Saling berkesinambungan satu dengan yang lain. Siswa yang memilki sikap positif terhadap IPA akan antusias dalam belajar dan membuat siswa akan tertarik untuk memperbanyak waktu belajar IPA selanjutnya siswa yang senang belajar IPA kemudian tertarik memperbanyak waktu beljar IPA akan muncul rasa ketertarikan berkarir di bidang IPA. Ketertarikan untuk melanjutkan karir dibidang IPA tidak lepas dari seberapa besar individu tersebut memiliki keyakinan bahwa berkarir dibidang IPA merupakan salah satu keinginan untuk masa depannya.

Penelitian dilaksanakan karena rasa keingintahuan peneliti pada indikator sikap kesenangan dalam belajar IPA, ketertarikan memperbanyak waktu belajar, dan ketertarikan berkarir di bidang IPA di MtS Syifa'ul Qulub. Pada penelitian sebelumnya [2] meneliti pada tingkat SMP yang berjudul Identifikasi Sikap Sosial Dari IPA, Ketertarikan Menambah Waktu Belajar IPA, dan Ketertarikan Berkarir Dibidang IPA Siswa SMP Se-Kabupaten Muaro Jambi. Disini ada kesamaan indikator yaitu, ketertarikan menambah waktu belajar IPA dan ketertarikan berkarir di bidang IPA penelitian tersebut didapatkan hasil yang tergolong rendah dengan sikap dominan yang cukup baik. Pada penelitian ini di MtS Syifa'ul Qulub sikap ketertarikan memperbanyak waktu belajar IPA juga tergolong rendah.

\section{KESIMPULAN}

Berdasarkan hasil penelitian yang telah dilakukan sikap kesenangan dalam belajar IPA di MtS Syifa'ul Qulub berada pada kategori Cukup dengan presentasi 52,1\% atau jumlah siswa 38 siswa. Untuk indikator ketertarikan memperbanyak waktu belajar IPA juga berada dalam kategori Cukup dengan presentase 74,0 \% atau 54 orang siswa, dan untuk indikator berkarir dbidang IPA juga berada dalam kategori Cukup dengan presentase 57,5\% atau 42 siswa.

Sesuai dengan tujuan pendidikan yang telah dipaparkan dalam pendahuluan bahwasanya pendidikan untuk mencipatakan manusia yang berkualitas, maka dalam proses pembelajaran hendaknya siswa senang dalam belajar dan dapat memperdalam ilmu pengetahuan IPA dengan memperbanyak waktu belajar IPA dan menyukai mata elajarn IPA sehingga nantinya akan membuat siswa tertarik berkarir di bidang IPA

\section{UCAPAN TERIMA KASIH}

Terima kasih kepada pihak sekolah MTS Syifa'ul Qulub yang telah berpartisipasi untuk kelancaran penelitian dan terima kasih kepada pihak-pihak yang telah memberi dukungan pada penelitian ini.

\section{REFERENCES}

[1] D. S. Putra, A. Lumbantoruan, \& S. C. Samosir, "Deskripsi Sikap Siswa: Adopsi Sikap Ilmiah, Ketertarikan Memperbanyak Waktu Belajar Fisika Dan Ketertarikan Berkarir di Bidang Fisika," Tarbiyah: Jurnal Ilmiah Kependidikan, vol. 8, no.2 9, pp.1-100, 2019

[2] Astalini, D. A. Kurniawan, \& A. D. Putri, "Identifikasi Sikap Implikasi Sosial Dari IPA, Ketertarikan Menambah Waktu Belajar IPA, Dan Ketertarikan Berkarir Di Bidang IPA Siswa SMP Se-Kabupaten Muaro Jambi,”. Jurnal Tarbiyah: Jurnal Ilmiah Kependidikan, vol 7 no. 2, pp. 93-108, 2018

[3] Darmaji, D. A. Kurniawan, \& A. Suryani, "Effectivinness Of Basic Physics II Praction Guildenes Based On Science Process Skills," JIPF (Jurnal Ilmu Pendidikan Fisika, Vol 4 no. 1. pp. 1, 2019

[4] D. S. Putra, \& O. H. Wiza, 2019. Analisis Sikap Siswa Terhadap Mata Pelajaran Fisika di SMA Ferdy Ferry Putra Kota Jambi. UPEJ, Vol 8 no 3. pp. 299-311, 2019

[5] K. Hardiyati, Astalini \& D. A. Kurniawan, "Sikap Siswa Terhadap Mata Pelajaran Fisika Di Sma Negeri 5 Muaro Jambi," EDU fisika Jurnal Pendidikan Fisika,vol 3 no. 2. pp. 1-12, 2018

[6] D. A. Kurniawan, Astalini, \& L. Anggraini, "Evaluasi Sikap Siswa SMP Terhadap IPA Di Kabupaten Muaro Jambi," Jurnal Ilmiah DIDAKTIKA, vol. 19 no. 1, pp. 124-139. 2018

[7] Astalini, D. A. Kurniawan, H. Pathoni, R. Perdana, "Identifikasi Sikap Peserta Didik terhadap Mata Pelajaran Fisika di Sekolah Menengah Atas Negeri 5 Kota Jambi," Unnes Physics Education Journal,Vol.8, No.1, pp. 3543,2019 
[8] D. A. Kurniawan, et al., Perception and attitudes toward science: condition of students in learning natural sciences in indonesia. International Journal of Scientific and Technology Research, vol. 8, no.10, pp. 2293-2298, 2019

[9] Astalini, D. A. Kurniawan, R. Perdana, W. Kurniawan, "Identification Attitudes of Learners on Physics Subjects," Journal of Educational Science and Technology (EST), Vol. 5, No. 1, pp. 39-48, 2019

[10] Astalini, D. A. Kurniawan, Darmaji, L. R. Sholihah, R. Perdana, "Characteristics Of Students' Attitude To Physics In Muaro Jambi High School,” Humanities \& Social Science Reviews (HSSR), Vol. 7, No. 2, pp. 91-99, 2019

[11] Astalini, D. A. Kurniawan, N. Kurniawan, L. Anggraini, "Evaluation of Student's Attitude Toward Science in Indonesia" Open Journal of Educational Research (OJER), Vol. 3, No. 1, pp. 1-12, 2019

[12] Astalini, D. A. Kurniawan, \& Sumaryanti. "Sikap Siswa Terhadap Pelajaran Fisika Di SMAN Kabupaten Batanghari," Jurnal Ilmu Pendidikan Fisika, vol. 3 no. 2, pp. 39-64. 2018

[13] L. Anggraini, \& R. Perdana. "Hubungan Sikap Dan Percaya Diri Siswa Pada Mata Pelajaran IPA Di SekolahMenengah Pertama,” SPEKTRA: jurnal Kajian Pendidikan Sains, vol. 5, no. 2, pp.188-199, 2019.

[14] Maison, Darmaji, Astalini, D. A. Kurniawan, P. S. Indrawati, "Science Process Skills And Motivation," Humanities \& Social Science Reviews (HSSR),Vol. 7, No.5, pp. 48-56, 2019

[15] Maison, Astalini, D.A. Kurniawan, R. Perdana, L. Anggraini, "The Phenomenon of Physicology Senior High School Education: Relationship of Students' Attitudes towards Physics, Learning Style, Motivation," Universal Journal of Educational Research. Vol. 7, No.10, pp. 2199-2207, 2019

[16] Astalini \& D. A. Kurniawan, "Pengembangan Instrument Sikap Siswa Sekolah Menegah Pertama Terhadap Mata Pelajaran IPA,” Jurnal Pendidikan Sains, vol. 7 no. 1, pp. 1-7, 2019

[17] J.W. Cresswell, "Educational Research: Planning, Conducting, And Evaluating Quantitative and Qualitative Research $4^{\text {th }}$ Edition," Pearson Education: USA, 2012.

[18] L.M Cohen, "Research Methods in Education," New York : Routledge. 2007

[19] Maison, et al., "Deskripsi Sikap Siswa Sma Negeri Pada Mata Pelajaran Fisika," EDUSAINS, vol. 10, no 1. 2018

[20] Darmaji, Astalini, D. A. Kurniawan, H. Parasdila, Irdianti, Susbiyanto, M. Ikhlas, Kuswanto. "E-Module Based Problem Solving in Basic Physics Practicum for Science Process Skills," International Journal of Online and Biomedical Engineering (IJOE), Vol. 15, No. 15, pp. 4-17, 2019

[21] D. Darmaji, D. A Kurniawa, and Irdianti, "Physics education students' science process skills," International Journal of Evaluation and Research in Education (IJERE), Vol.8, No.2, pp. 293-298, 2019

[22] Asrial, Syahrial, D. A. Kurniawan, M. Subandiyo, N.Amalina, "Exploring obstacles in language learning among prospective primary school teacher," International Journal of Evaluation and Research in Education (IJERE), Vol.8, No. 2, pp. 249-254, 2019

[23] Asrial, Syahrial, D. A. Kurniawan, R. Perdana, and P. Nugroho, "Supporting Technologi 4.0: Ethnoconstructivist Multimedia for Elementary Schools" International Journal of Online and Biomedical Engineering (iJOE), Vol.15, No. 9, pp. 4-15, 2019

[24] D. A. Kurniawan, Asrial, Syahrial, W. S. Salsabila, E. F.Kurniawati, Q. S. Anandari, R. Perdana, A. Lumbantoruan, N.R. Nasih, S. C. Samosir, U.P. Dewi, "Etnoscience Investigation in Pimary Schools: Impact on Science Learning," Universal Journal of Educational Research Vol. 7, No.12, pp. 2789-2795, 2019.

[25] Syahrial, Asrial, D. A. Kurniawan, F. Chan, A. Hariandi, R. A. Pratama, P. Nugroho, R. Septiasari, “The Impact of Ethnoconstructivism in Social Affairs on Pedagogic Competences," International Journal of Evaluation and Researcn in Education (IJERE), Vol.8, No.3, pp.409-416, 2019

[26] Syahrial, Asrial, D. A.Kurniawan, P. Nugroho, R. Septiasari, R. A. Pratama, R. Perdana, "Increased Behavior of Students' Attitudes to Cultural Values using the Inquiry Learning Model Assisted by Ethnoconstructivism," Journal of Educational Science and Technology, Vol.5, No.2, pp. 176-188, 2019

[27] R. Darmawangsa, Astalini \& D. A. Kurniawan, "Pengembangan Instrumen Sikap Siswa Sekolah Menengah Atas terhadap Mata Pelajaran Fisika," Jurnal Pendidikan Fisika, vol. 6, no. 1, pp. 107-114, 2018.

[28] Astalini, dkk., "Sikap Terhadap Mata Pelajaran Ipa Di Smp Se-Kabupaten Muaro Jambi," LENTERA PENDIDIKAN, vol. 21, no 2, pp. 214-227. 2018. 